\title{
Структура фізичної реабілітації в гострому періоді у хворих комбустіологічного профіля
}

\author{
УДК 617.717.001.17
}

\author{
О. І. Осадча', О. О. Шматова', Г. М. Боярська²
}

${ }^{1}$ Національний університет фізичного виховання і спорту України, Київ, Україна ²ДУ «нститут гематології та трансфузіології НАМНУ», Київ, Україна

\begin{abstract}
Резюме. У опікових хворих, внаслідок неминучого збереження косметичного дефекту після травми, хоча і за наявності позитивних функціональних результатів лікування, реабілітації відводиться першочергове значення. Фізична реабілітація пацієнтів з опіками послідовно проводиться в усі періоди опікової хвороби. Превентивна реабілітація (перший етап) проводиться в гострий період травми в процесі відновлення втраченого шкірного покрову. На другому етапі - ранньої консервативноїреабілітації, коли після закриття ран відбувається інтенсивне формування рубцевої тканини, консервативні заходи спрямовані на обмеження, розм'якшення рубців і профілактику деформацій і контрактур.
\end{abstract}

Ключові слова: опіки, опікова хвороба, періоди опікової хвороби, фізична реабілітація.

Physical rehabilitation structure during acute period in patients of combustiological profile O. I. Osadcha', O. O. Shmatova', H. M. Boiarska²

${ }^{1}$ National University of Physical Education and Sport of Ukraine, Kyiv, Ukraine 2"Institute of Hematology and Transfusiology of NAMSU" GO, Kyiv, Ukraine

\begin{abstract}
In patients with burn injury, due to the inevitable preservation of a cosmetic defect after injury, although in the presence of positive functional results of treatment, rehabilitation is of paramount importance. Physical rehabilitation of burn patients is consistently carried out during all periods of burn disease. Preventive rehabilitation (the first stage) is carried out in the acute period of trauma in the process of restoring the lost skin. At the second stage (early conservative rehabilitation), when, after closure of wounds, there is an intensive formation of scar tissue, conservative measures are aimed at limiting, softening scars and preventing deformities and contractures

Keywords: burns, burn disease, periods of burn disease, physical rehabilitation.
\end{abstract}

Постановка проблеми. За даними ВООЗ опіки займають третє місце серед інших травм, а в деяких країнах - друге, поступаючись лише транспортним травмам. В останні роки кількість опіків в Україні зменшилась і становить у середньому 50 тис. на рік (у тому числі 9 тис. - діти) $[6,8]$.

Проблема опіків надзвичайно різноманітна і охоплює багато різних питань, у тому числі й стосовно реабілітації.

Під термічними опіками розуміють ураження тканин, що виникли під впливом високої температури, в результаті дії полум'я, гарячих рідин та предметів, розплавленого металу. Залежно від глибини ураження тканин розрізняють чотири ступеня опіків; I і || відносять до поверхневих, оскільки в процес втягуються верхні шари шкіри. Вони характеризуються почервонінням, припухлістю, болем і пухирцями з рідинним вмістом (II ступінь). При III ступені частково пошкоджується ростковий шар шкіри (III-A) чи гинуть всі iï шари (III-Б), а при IV ступені омертвіння поширюється на тканини, що лежать глибше. Опіки III-Б і IV ступенів належать до глибоких. Тяжкість ураження при опіках пропорційна їх площі і ступеню, а також залежить від локалізації травми. При великих поверхневих або глибоких опіках, крім місцевих проявів, виникає загальна реакція організму, що отримала назву опікової хвороби [1, 6-8]. 
Опікова хвороба - це симптомокомплекс, який розвивається у разі, коли площі опікової рани становить понад 10-15\% поверхні тіла у дорослих і 5-7 \% у дітей, коли виникають фрункціональні та морфологічні зміни з боку життєво важливих органів і систем, коли спостерігаються розлади гемодинаміки, порушення обмінних і нейрогуморальних процесів, розвивається опіковий шок.

У клінічній картині опікової хвороби відмічають чотири періоди:

- опіковий шок (1-3 доби);

- гостра опікова токсемія (3-7 діб);

- септикотоксемія (з 8-ї доби до відновлення шкірного покриву);

- реконвалесценція (з відновлення шкірного покриву до відновлення функцій органів і систем) [6].

Фізична реабілітація при опіках застосовується під час консервативного і хірургічного лікування. Використання іï засобів, послідовність i методика застосування базуються на загальних принципах: вони залежать від ступеня, площі і локалізації ураження, перебігу захворювання, віку, методів лікування, рухового режиму, періоду і етапу реабілітації [2].

Мета дослідження - визначити основні принципи фрізичної реабілітації хворих комбустіологічного профілю в гострий період хвороби.

Матеріал та методи дослідження. Аналіз та узагальнення науково-методичної літератури.

Результати дослідження та їх обговорення. Значення фрізичної реабілітації при опіках важко переоцінити. На сьогодні загальновизнано, що два методи - спокій та рух - не повинні виключати один одного. Правильне поєднання спокою і рухів в рамках лікувального рухового режиму дозволяє прискорити терміни клінічного і фрункціонального одужання, забезпечує найбільш швидке і всебічне відновлення працездатності.

Основні впливи на організм в разі термічної травми розподіляються на місцеві та загальні.

Місцеві обумовлені порушенням анатомічної цілісності тканин і їх функцій:

- гіпотрофія, атрофрія м>язів, зниження їх тонусу, сили;

- обмеження обсягу рухів у суглобах, обмежена рухомість;

- погіршення периферичного кровообігу;

- венозний застій;

- погіршення лімфатичної мікроциркуляції (лімсоостаз);

- розвиток контрактур, сполучнотканинних процесів, грубих рубців і т.д.
Загальні обумовлені зміною діяльності ЦНС - формуванням в корі головного мозку патологічних вогнищ, іррадіація з яких викликає розлади фрункціонування в системах життєзабезпечення:

- системі кровообігу (тахікардія, гіпотонія);

- системі дихання (застійна «гіпостатичная» пневмонія);

- системі травлення (зниження апетиту, закрепи, проноси);

- системі виділення (затримка сечовипускання або нетримання сечі);

- психоемоційної сорери (погіршення настрою, депресія) та ін.

У комбустіології весь курс реабілітації поділяють на три періоди, а саме:

- імобілізаційний;

- постімобілізаційний;

- відновний.

Основними принципами реабілітації при опіках $€$ ранній її початок, чіткий план реабілітаційних заходів, виключення періодів тривалої нерухомості, постійне нарощування рухової активності.

Реабілітаційні дії при опіковій хворобі починають застосовувати після виходу хворого з опікового шоку. У цей період застосовувати реабілітаційні засобі категорично заборонено. Обсяг фрізичних вправ має відповідати призначеному руховому режиму. Основна мета фрізичних вправ полягає у дотриманні суворого постільного режиму - це психотерапевтичний вплив на хворого і попередження легеневих ускладнень.

У ранній післяшоковий період, якщо це можливо та відповідає стану хворого, допускаються рухи з невеликою амплітудою в дистальних відділах кінцівок; проводять лікування положенням, яке передбачає встановлення сегмента чи кінцівки у функціонально вигідну позицію, що перешкоджає утворенню контрактур.

У стадії токсемії, зважаючи на стан хворого, проводять вправи на покращення функції легень, для профілактики розвитку запалення легень та покращення кровообігу. Вправи призначають 3 метою покращення та нормалізації функції центральної нервової системі, роботи органів травлення, а також профрілактики ускладнень 3 боку інших органів та систем організму. Значну увагу приділяють відновленню рухливості суглобів, розвитку атрофії м'язів, покращенню лімфо- та кровообігу пошкоджених кінцівок, що сприяє поліпшенню результатів оперативного лікування.

Вправи призначають з урахування суб'єктивного стану хворого та об'єму хірургічного етапу 
лікування. Рухи проводять в уповільненому темпі, $з$ невеликою амплітудою. При неможливості їх виконання ушкодженими сегментами застосовують статичні напруження м'язів, надсилання імпульсів до кінцівок, а також рухи у здорових симетричних ділянках $[2,3,5]$.

У подальшому комплекси доповнюють вправами для відновлення функціонування суглобів у зоні ушкодження. Вправи на розтягнення рекомендують проводити під час перев'язок у теплій ванні, що сприяє збільшенню амплітуди рухів, зменшує біль. Призначають загальнорозвиваючі вправи, основою яких є дихальні вправи і рухи в здорових симетричних ділянках. Приділяють увагу вправам, що сприяють формуванню компенсацій, навичок самообслуговування [3].

Під час фрізичної реабілітації хворим проводять неоднаразові хірургічні втручання. При цьому слід враховувати певні етапи фрізичної реабілітації, такі, як доопераційний період (пов'язаний з підготовкою хворого до вручання), та післяопераційний період (зниження ризику розвитку післяопераційних ускладнень).

Доопераційний період має включати дихальні вправи, вправи для неушкоджених м'язів і кінцівок та на зниження емоційного напруження.

Основними завданнями фрізичної реабілітації в доопераційний період мають бути:

- зниження емоційного напруження у хворого перед операцією;

- поліпшення функціонального стану серцево-судинної та дихальної систем;

- поліпшення кровообігу в ураженому і донорському сегментах тіла;

- навчання грудному типу дихання за необхідності вимушеного положення тіла на животі після операції.

Застосовують дихальні, загальнорозвиваючі й спеціальні вправи (залежно від локалізації опіку).

Післяопераційний період включає фрізичні вправи малої амплітуди у повільному темпі, дихальні вправи, вправи, призначені для покращення крово- та лімфрообігу.

Після операції в комплекс включають статичні й динамічні дихальні вправи та нескладні загальнорозвиваючі вправи для дистальних відділів кінцівок. Рухи в оперованій області слід починати не раніше ніж на 6-7-й день після хірургічного втручання, щоб не викликати напруження м'язів і не змістити шкірні трансплантати. У прооперованій зоні на 6-7-й день після операції рухи мають бути спочатку тільки пасивні або активні, які вимагають невеликої амплітуди і зусилля. Вправи у воді можливі не раніше, ніж через 1-2 міс. після отриманої травми.
Основними завданнями у цей період є:

- профрілактика післяопераційних ускладнень (пневмонії, тромбофрлебіту, атонії кишечника);

- покращення діяльності серцево-судинної і дихальної систем;

- активізація кровотоку в донорському сегменті тіла і в місці пересадки тканин для прискорення загоєння;

- профрілактика обмеженої рухливості суглобів і атрофрії м'язів.

При розвитку опікового виснаження, ускладненнях III періоду, необхідно знизити фрізичне навантаження у хворих з вираженою атрофрією м'язів і стійкими розладами діяльності серцево-судинної та інших систем. Заняття проводять обережно, вправи мають бути спрямовані на підвищення загального тонусу, підтримання діяльності основних систем організму, на боротьбу з атрофрією, контрактурами і обмеженою рухливістю суглобів. Вправи виконують з полегшених вихідних положень, у теплій ванні, а рухи в ушкоджених ділянках - 3 невеликою амплітудою і у повільному темпі.

Лікувальний масаж у разі опікової хвороби починають використовувати після очищення опікової поверхні від відмерлих тканин і закриття ран, тобто у період одужання. Завдання масажу: поліпшення крово- і лімфообігу в ділянці опіку, сприяння розм'якшенню і утворенню еластичних рубців, розтягнення спайок, стимуляція скорочувальної фрункції м'язів, протидія контрактурам і обмеженій рухливості у суглобах. Застосовують сегментарно-рефлекторний масаж відповідних паравертебральних зон спинномозкових сегментів, масаж симетричних здорових ділянок тіла та м'язів (антагоністів) протилежного боку локалізації опіку. Ці м'язи, звичайно, розтягнуті й ослаблені. Тому для стимуляції їх скоротливої здатності використовують глибоке прогладжування, розтирання сухожилків, пиляння, пересікання, стругання, поперечне розминання, безперервну вібрацію, поплескування. На боці опіку травмовану поверхню не масажують, ії̈ обходять, застосовуючи ніжні прийоми. Роблять масаж суглобів, котрі втягнуті у контрактуру. Одночасно з масажем виконують активні і пасивні рухи. 3 утворенням рубця починають обережно масажувати поверхню опіку.

Протипоказаннями до призначення фрізичної реабілітації є:

- загальний важкий стан хворого, обумовлений крововтратою, шоком, інфекцією, психологічною травмою, супутніми захворюваннями;

- стійкий виражений больовий синдром (нестерпні болі). 
- підвищення температури тіла понад $37,5{ }^{\circ} \mathrm{C}$.

- небезпека кровотечі або відновлення кровотечі в зв'язку з рухами.

- наявність сторонніх тіл поблизу великих судин, нервів та інших життєво важливих органів.

\section{Висновки}

1. Фізична реабілітація - це процес, при якому пацієнтові допомагають досягти максимального потенціалу після хвороби або травми. У опікових хворих, внаслідок неминучого збереження косметичного дефекту після травми, хоча і за наявності позитивних фрункціональних результатів

\section{Література}

1. Жернов ОА, Осадча ОІ, Жернов АО. Лікування післяопікових та післяопераційних рубців із застосуванням препаратів крем Карипаїн та гель Карипаїн ультра [Treatment of post-burn and postoperative scars with the use of Caripain cream and Caripain ultra gel]. Клінічна хірургія. 2011; 7: 60-4. 1.

2. Каніщева ОП, Вялих ОМ. Лікувальна фізична культура при опіках різного ступеня [Therapeutic physical culture for burns of varying degrees]. Фізична реабілітація та рекреаційно-оздоровчі технології. 2016; 2: 34-6.

3. Медицинская реабилитация Т. 2 Под редакцией В. М. Боголюбова. Москва, 2007. 475 с.

4. Мелешков ВА. Применение лечебной физической культуры при обширных поверхностных ожогах I-II степени [The use of physical therapy

osadchay1965@gmail.com лікування, реабілітації відводиться першочергове значення.

2. Фізична реабілітація пацієнтів з опіками послідовно проводиться в усі періоди опікової хвороби. Превентивну реабілітацію (перший етап) проводять у гострий період травми в процесі відновлення втраченого шкірного покрову. На другому етапі (ранньої консервативної реабілітації), коли після закриття ран йде інтенсивне формування рубцевої тканини, консервативні заходи спрямовані на обмеження, розм'якшення рубців і профрілактику деорормацій і контрактур.

for extensive superficial burns of the I-II degree]. Слобожанський науковоспортивний вісник. 2015; 5 (49): 68-3.

5. Попов СН. Лечебная физическая культура (учебник для студ высш. учеб. заведений). Москва: Академия; 2014. 416 с.

6. Kozynets HP, Osadcha OI, Boiars'ka HM, Tsyhankov VP, Nazarenko VM, Solodky IA. Determination of clinical efficacy of REGEN-D 150 preparation for local treatment of burns. 2011; 7: 65-8.

7. Kovalenko OM, Osadcha OI, Kovalenko AO, et al. Diagnosis and treatment algorithm of burn sepsis. Shpytalna khirurhiia. 2013; 3: 65-7.

8. World Health Organisation. Burns. 2018. https://www.who.int/newsroom/fact-sheets/detail/burns. 